\title{
Globalisasi Komunikasi dan Dampak Sosial di Masyarakat Perkebunan (Studi Kasus Masyarakat Perkebunan di Sumatera Utara)
}

\section{Globalization of Communication and Social Impact in Plantation Communities (Case Study of Plantation Communities in North Sumatera)}

\author{
Selamat Riadi \\ Program Studi Komunikasi dan Penyiaran Islam, Universitas Islam Negeri (UIN) Sumatera Utara, Indoonesia \\ email: selamatriadi.kom@gmail.com
}

\begin{tabular}{ccc}
\hline First received: & Revised: & Final Accepted: \\
5 May 2020 & 17 May 2020 & 4 June 2020 \\
\hline
\end{tabular}

\begin{abstract}
Community communication effectiveness in plantations we can put it together in the form of internal and external problems. Effectiveness is the goal of the ability to utilize something right, clear and universally acceptable standard. Community and plantation company conflicts are natural resource conflicts based on the struggle for natural resources. This problem can have an impact on socio-cultural aspects so that it refers to communication problems. The ability to approach problems must be able to master the negotiation, both the ability to dialogue, humility, trust, hope and critical thinking, so that problems in the garden do not expand and will not benefit all parties.
\end{abstract}

Keywords : Communication Effectiveness; Plantation Conflict.

\section{ABSTRAK}

Efektivitas komunikasi Masyarakat di Perkebunan dapat kita satukan dalam bentuk masalah internal maupun eksternal. Efektivitas merupakan tujuan dari kemampuan untuk mendayagunakan sesuatu secara tepat, standar yang jelas dan dapat diterima secara universal, Konflik perusahaan masyarakat dan perkebunan adalah konflik sumber daya alam yang didasarkan pada perjuangan untuk sumber daya alam. Permasalahan ini bisa berdampak pada aspek sosial budaya hingga merujuk kepada permasalahan komunikasi. Kemampuan pendekatan permasalahan harus mampu penguasaan negoisasi, baik kemampuan dialog, kerendahan hati, kepercayaan, harapan dan pemikiran kritis, agar permasalah dalam kebun tidak meluas dan akan tidak menguntungan semua pihak.

Kata kunci : Efektivitas Komunikasi; Konflik Perkebunan.

\section{PENDAHULUAN}

Efektivitas komunikasi menjadi sangat mendukung untuk memberikan pemahaman bahwa di perkebunan memiliki kebiasaan yang disebut budaya kebun. Sehingga seorang pemimpin dapat memahami bahwa ini merupakan sistem yang mengikat di dunia perkebunan dan membiasakan perilaku menjadi seorang asisten. Maksudnya bagaimana bagaiman seorang asisten dapat diterima di masyarakat perkebunan, dan bertujuan melihat sejauh mana efektifitas komunikasi seorang asisten yang berpengaruh atau memberikan tentang aplikasi kebun, bagaimana cara mengatur dan memberikan masukan perintah tersebut.

Dalam komunikasi seorang asisten efektif dituntut untuk berperan dan bertanggungjawab, sehingga asisten dituntut memiliki kemampuan berkomunikasi efektif. Asisten perlu menyadari akan hal ini, yaitu bahwa di dalam melaksanakan kegiatan belajar dan pembelajaran, sebenarnya sedang melaksanakan kegiatan komunikasi. 
Perkebunan yang dalam sejarahnya perkembangan perkebunan di negara berkembang termasuk di Indonesia, tidak dapat dipisahakan dari sejarah perkembangan kolonialisme, kapitalisme, dan modernisasi. Di negara berkembang, pada umumnya perkebunan hadir sebagai perpanjangan dari perkembangan kapitalisme agraris barat yang diperkenanlakan melalui sistem perekonomian kolonial. Sebelum barat memperkenalkan sistem perkebunan, masyarakat agragris indonesia telah mengenal sistem kebun sebagai sistem perekonomian tradisional. Usaha kebun dijadikan usaha pelengkap atau sampingan dalam kegiatan pertanian pokok. Dan sejalan dengan itu barat juga memperkenalkan sistem perkebunan besar dimana perkembangan perkebunan mengalami modifikasi baik dalam produktivitas maupun pengelolaannya yang sekarang kita kenal dengan perekebunan modern.

Dewasa ini perkebunan memasuki tahap dimana perkebunan mengalami perkembangan pesat yang sangat mempengaruhi sektor perekonomian yang dikuasai oleh negara, swasta, dan asing yang dimana memberikan kontribusi bagi keberlangsungan pembangunan di Indonesia dalam sektor ekonomi.

Perkembangan pengelolaan perkebunaan itu sendiri tidak terhindarkan adalah masalah atau dampak yang timbul yang menunjukkan adanya sektor lain yang masih timpang. Masalah diperkebunan dapat dirasakan dengan adanya aspek yang tidak diperhitungkan. Masalahmasalah itu kemudian rampung dan mengancam akan keberadaaan perkebunan itu sendiri.

Permasalahan dalam perkebunan bisa dilihat dari sektor menurunnya hasil produktivitas perkebunan selain masalah berkaitan dengan produktivitas juga adalah masalah yang timbul dari berkembangnya sistem budaya kapitalis yang mengakibatkan adanya masalah eksteren. Permasalahan ini bisa berdampak pada aspek sosial budaya hingga merujuk kepada permasalahan komunikasi.

Efektivitas komunikasi Masyarakat di Perkebunan dapat kita satukan dalam bentuk masalah internal maupun eksternal. Dan pada akhirnya akan memepengaruhi eksistensi perkebunan itu dalam budaya masyarakat.

\section{METODE PENELITIAN}

Penelitian ini dilakukan dengan pendekatan kualitatif. Metode yang dilakukan adalah dengan cara penelitian lapangan (field research). Penelitian lapangan yaitu penelitian yang mencari dan mengumpulkan data-data dari lapangan atau lokasi penelitian. Dalam penelitian lapangan, peneliti secara individu berbicara dan mengamati secara langsung objek yang sedang diteliti. Melalui interaksi akan diperoleh ahal mendasar dari apa yang peneliti lakukan.

\section{HASIL PENELITIAN DAN PEMBAHASAN}

\section{Efektivitas Komunikasi}

Ditinjau dari prosesnya, Komunikasi dalam arti bahwa dalam proses tersebut terlibat dua komponen yang terdiri atas manusia, yakni pengajar sebagai komunikator dan mahasiswa sebagai komunikan. Lazimnya pada tingkatan bawah dan menengah pengajar itu.Tujuan pendidikan adalah khas atau khusus yaitu meningkatkan pengetahuan seseorang mengenai suatu hal sehingga dapat dikuasai dan tujuan pendidikan itu akan tercapai jika prosesnya komunikatif karena jika prosesnya tidak komunikatif maka tujuan pendidikan tidak dapat tercapai (Dharma, 2016).

Menurut Onong menyatakan komunikasi dalam bentuk diskusi dua arah dalam proses belajar mengajar berlangsung sangat efektif, baik antara pengajar dengan mahasiswa maupun diantara para mahasiswa sendiri sebab mekanismenya memungkinkan si mahasiswa terbiasa mengemukakan pendapat secara argumentatif (Onong, 1999).

Menurut Friere dalam (Dharma, 2016). Dialog tidak pernah terjadi apabila prasyarat untuk melakukan dialog tidak terpenuhi. Dialog merupakan situasi belajar yang mewajibkan 
adanya syarat-syarat yang harus terpenuhi sebagai berikut, Pertama, perhubungan dialogis, merupakan situasi belajar yang esensial bagi proses mengetahui. Perhubungan dialogis adalah komunikasi dan interkomunikasi antara orang kebal terhadap birokrasi kesadaran dan terbuka untuk penemuan dan untuk mengetahui lebih banyak. Kedua, cinta, dialog merupakan laku penciptaan dunia oleh para manusia yang mencintai dunia, mencintai sesama manusia dan mencintai kehidupan. Cinta merupakan pondasi dari dialog.

Ketiga, kerendahan hati, Dialog tidak dapat terwujud tanpa kerendahan hati. Penamaan dunia, proses orang-orang mere-kreasi dunia secara menetap, tidak dapat berupa suatu tindakan arogansi. Keempat, keyakinan mendalam terhadap manusia, syarat dialog selanjutnya adalah keyakinan, yakin terhadap manusia yang mampu menamai dunia, merkreasi dunia, serta mewarnai dunia dengan segala potensi yang beragam. Dialog hanya bisa terjadi dengan keyakinan terhadap fitrah manusia sebagai mahluk yang otonom, memiliki kemampuan untuk subjek-subjek yang memiliki daya transformatif. Kelima, kepercayaan, mendasarkan pada cita, kerendahan hati dan keyakinan, maka dialog akan menjadi sebuah bentuk hubungan horizontal di mana sifat saling mempercayai diantara pelakunya merupakan konsekuensi logis.

Keenam, harapan, dialog merupakan laku para subjek yang mencintai kehidupan, kehidupan yang mengharapkan perubahan-perubahan yang lebih baik, Harapan berakar dalam ketidaksempurnakan manusia, dari sini harapan bergerak dengan pencarian terus menerus sebuah pencarian yang hanya dapat dilaksanakan melalui dialog dengan orang lain membisu, melemah, tenggelam, bahkan lari dari kenyataan. Ketujuh, pemikiran kritis, dialog yang benar tidak dapat terjadi jika para partisipan tidak terlihat dalam berpikir kritis. memandang bahwa: "Pemikiran kritis adalah pemikiran yang melihat suatu hubungan tak terpisah antara manusia dan dunia tanpa melakukan dikhotomi diantara keduanya- pemikiran yang memandang realitas sebagai proses dan perubahan, ketimbang sebagai suatu entitas yang statis- pemikiran yang tidak memisahkan pemikiran itu sendiri dari tindakan, tetapi senantiasa bergumul dengan masalah-masalah dunia tanpa gentar menghadapi resiko".

Efektivitas merupakan wujud dari kemampuan untuk mendayagunakan sesuatu secara tepat sesuai dengan standar yang jelas dan dapat diterima secara universal. Dalam konteks ini efektivitas menunjukkan taraf mencapai tujuannya secara ideal, tarap efektivitasnya dapat dinyatakan dengan ukuran-ukuran yang agak pasti. Pandangan ini memfokuskan bahwa efektivitas adalah kemampuan untuk mencapai suatu tujuan dengan ukuran yang pasti.

Menurut Dirman Dikatakan komunikasi yang efektif apabila terdapat aliran informasi dua arah antara guru sebagai komunikator dan peserta didik sebagai komunikan dan informasi tersebut sama-sama direspon sesuai dengan harapan guru maupun perserta didik tersebut.

Dalam membangun komunikasi yang efektif dengan peserta didik, stidaknya guru perlu memahami lima aspek sebagai berikut, Pertama, kejelasan, Bahwa dalam komunikasi dengan peserta didik, guru harus mengunakan bahasa dan mengemas informasi secara jelas, sehingga mudah diterima dan dipahami oleh peserta didik. Kedua, Ketepatan atau akurasi ini menyangkut pengunaan bahasa yang benar dan kebenaran informasi yang di sampaikan. Dalam komunikasi dengan peserta didik, guru harus mengunakan bahasa yang baik dan benar serta informasi yang disampaikan juga harus benar. Ketiga, Konteks atau sering disebut dengan situasi, maksudnya adalah bahwa bahasa dan informasi yang disampaikan harus sesuai dengan keadaan dan lingkungan dimana komunikasi itu terjadi. Guru dalam berkomunikasi perlu memperhatikan keadaan dan situasi yang dihadapi. Keempat, Alur Bahasa dan informasi yang disajikan oleh guru dalam berkomunikasi dengan peserta didik harus disusun dengan alur dan sistematika yang jelas, sehingga pihak yang menerima informasi yaitu peserta didik cepat tanggap. Kelima, Budaya Aspek ini tidak hanya menyangkut bahasa dan informasi tetapi juga berkaitan dengan tatakrama dan etika. Artinya dalam berkomunikasi dengan peserta didik, guru harus menyesuaikan dengan budaya peserta didik, baik dlam pengunaan bahasa verbal maupun nonverbal, agar tidak menimbulkan kesalahan persepsi (Dirman, 2014). 
(Hasbiansyah, 1996) Dosen Fakultas Ilmu Komunikasi Unisba. Menurut riset yang dilakukan selama lima belas tahun kepada para lulusan MIT (Massachusetts Institute of Technology), komunikasi efektif (effective communication) merupakan salah satu keahlian yang amat penting untuk mencapai keberhasilan dan kebahagiaan hidup menurut Stewart L.Tubbs dan Sylvia Moss dalam (Hasbiansyah, 1996). Kemampuan berkomunikasi secara efektif merupakan kemampuan istimewa bagi pengembangan kepribadian manusia dan juga karirnya di dunia kerja. Oleh karena itu, memahami bagaimana komunikasi beroperasi secara efektif sangat penting.

Secara sederhana, komunikasi itu disebut efektif apabila pemahaman penerima sama dengan pemahaman pengirim atas pesan yang disampaikan. Sesungguhnya, bagi Stewart L. Tubbs dan Sylvia Moss, ini baru salah satu unsur dari kriteria efektivitas komunikasi. Menurut mereka, komunikasi yang efektif paling tidak dicirikan oleh lima hal: membangun pengertian yang sama, mengembangkan rasa senang, mengubah sikap ke arah yang dikehendaki, membangun hubungan sosial yang baik, dan menimbulkan tindakan sesuai yang diharapkan

Siagian, mengemukakan bahwa efektivitas adalah "pemanfaatan sumber daya, dana, sarana dan prasarana dalam jumlah tertentu yang secara sadar diterapkan sebelumnya untuk menghasilkan sejumlah barang atau jasa dengan mutu tertentu tepat pada waktunya”. Hal ini menunjukkan bahwa efektivitas adalah, Pertama, Sebagai suatu kegiatan yang tepat sasaran, berdaya guna dan berhasil guna untuk mencapai tujuan dalam implementasi suatu kegiatan tertentu. Untuk mengetahui tingkat efektivitas sesuatu kegiatan biasanya dilakukan dengan membandingkan antara prestasi saat ini dengan prestasi yang diperoleh apabila semua sumber daya yang dimilikinya dikelola secara optimal dan objektif. Kedua, Secara teknis pengertian efektivitas merupakan suatu keadaan yang menunjukkan tingkat keberhasilan atau kegagalan kegiatan manajemen dalam mencapai tujuan. Diakui bahwa terdapat tiga dimensi yang kritis yang patut dipertimbangkan dalam mengamati tingkat efektivitas suatu organisasi atau kelompok yaitu: (a) keluaran yang dihasilkan, (b) kepuasan para anggota, dan (c) pertumbuhan dan pengembangan staf, baik yang menyangkut keterampilan dan kecerdasan individu maupun yang terkait dengan proses interaksi yang positif dalam pelaksanaan tugas (Siagian, 1997).

Robbins, mengemukakan bahwa untuk mengukur efektivitas dapat digunakan empat model pendekatan yaitu, Pertama, pendekatan pencapaian tujuan (Goal attainmet), Kedua, pendekatan sistem yang menekankan stabilitas, Ketiga, pendekatan konstituensi strategis yang menekankan terpenuhinya tuntutan stakeholder, dan Keempat, pendekatan nilai-nilai bersaing yang mempertemukan tiga kriteria yaitu human relation model, open system model dan rational goad model (Robbins, 2001).

Untuk itu efektivitas tidak boleh lepas dari faktor tujuan, faktor manusia, faktor nilainilai dan faktor sistem organisasi itu sendiri yang dihubungkan dengan kondisi waktu, target, jumlah, serta kualitas. Dengan demikian efektivitas ternyata bersifat multidimensional, sehingga strategi yang dipilih untuk meningkatkan efektivitas tergantung pada kekhususan atau spesifikasi faktor dari permasalahan yang hendak dipecahkan. Yang perlu digaris bawahi bahwa sesuatu yang efektif belum tentu efisien, demikian sebaliknya sesuatu yang efisien belum tentu efektif, namun perlu ditegaskan kembali bahwa jika sesuatu kegiatan atau aktivitas telah terbukti ketidak efektifannya maka tidak perlu lagi mempersoalkan efisiensinya.

\section{Masyarakat di Perkebunan}

Seorang Assisten Kebun adalah Orang yang diberikan tanggung jawab untuk memimpin afdeling (bagian/unit kebun) atau bagian/unit di pabrik dan berperan sebagai pembantu/membantu, bisa Membantu Manager dan Karyawan dalam melaksanakan segala jenis pekerjaan di lapangan, dan masyarakat di perkebunan adalah sektor penting dalam perekonomian Indonesia. Sumbangan yang diberikan pada masyarakat perkebunan utamanya adalah menghasilkan devisa melalui ekspor hasil-hasil perkebunan itu sendiri. Dalam tahun- 
tahun terakir lebih kurang 70 peresen dari nilai seluruh ekspor Indonesia berasal dari sektor perkebunan.

Perkebunan dapat dibagi dalam dua golongan, yaitu perkebunan rakyat dan perkebunan besar. Perkebunan rakyat ialah usaha tanaman yang dimiliki dan diselenggarakan atau dikelola oleh perorangan dan tidak berebadan hukum, dengan luas maksimal 25 hektar atau pengelola tananam perkebunan yang memepunyai jumlah pohon yang dipelihara lebih dari batas minimum usaha (BMU). Perkebunan rakyat mempunyai peran yang strategis dalam meningkatkan peran subsektor perkebunan kedepan, mengingat pangsa perkebunan rakyat menempati posisi yang paling besar baik dilihat dari luas areal maupun produksinya.

Perkebunan rakyat maka tidak lepas dari adanya perkebunan besar dimana perkebunan besar adalah perkebuan yang diselenggarakan atau dikelola secara komersial oleh perusahaan yang berbadan hukum. Perkebunan besar, terdiri dari : perkebunan besar negara (PBN) dan perkebunan besar swasta (PBS) nasiona/asing. Tantangan Asisten diperkebunan di Indonesia pada umumnya akan mengalami permasalahan diperkebunan. Adapun yang menjadi gambaran permasalahannya adalah sebagai berikut:

\section{Masalah Internal Dalam Perkebunan}

Masalah internal kemunduran hasil-hasil produksi. Faktor-faktor yang menyebabkan kemunduran ini diantaranya adalah kurangnya prasarana, kurangnya pembiayaan, Kekurangan tenaga ahli dibidang management dan komersil, tidak adanya penanaman modal baru, yang pada akhirnya memberikan dampak negatif bagi perkebunan, dengan hal-hal seperti diatas membuat sangat dirasakan terutama bagi masyarakat perkebunan, sangat rentan dengan masalah- masalah dalam pekerjaannya.

Diperkebunan masyarakat sangat terasa kurangnya efektivitas komunikasi, sehingga dari pe-kebun tidak mengetahui mengenai perkembangan-perkembangan teknologi baru, benihbenih unggul, sarana baru yang lebih produktif dan perkembangan-perkembangan harga. Yang terakhir seharusnya sangat penting masalah konflik lahan, tapal batas, serta adat disisi lain perusahaan juga harus untuk ditingkatkan data tawar mereka dalam menghadapi perantara dalam proses jual beli produksi.

\section{Masalah Eksternal Dalam Perkebunan}

Masalah eksternal dalam perkebunan berupa masalah sosial dalam perkebunan. masalah sosial yang terdapat di perkebunan adalah masalah konflik. Konflik Masyarakat dan Perusahaan Perkebunan Konflik sumberdaya alam adalah manifes maupun laten di sekitar dan berbasiskan perebutan sumberdaya alam. Pelaku konflik sendiri bias perusahaan, masyarakat maupun pemerintah dengan sebab, intensitas keterlibatan dan pola yang berbeda antar para pelaku konflik tersebut. Konflik sumberdaya alam ini senantiasa terkait sebagai strategi pemenuhan kebutuhan kebutuhan nafkah secara individual dan rumah tangga, penggerakan ekonomi di tingkat lokal, wilayah dan nasional hingga isu lingkungan fisik sosial disekitar kegiatan eksplorasi dan eksploitasi sumberdaya alam. Dalam konteks HAM, perubahan struktur sumber daya alam sejatinya menghilangkan hak ekonomi dan sosial (EkoSos) masyarakat lokal. Bagi masyarakat lokal yang hidup dengan budaya subsistensi, perubahan struktur sumber daya alam dapat menutup akses masyarakat lokal untuk memperoleh dan menikmati kekayaan sumber daya alam seperti mencari ikan, berburu,berladang, bertani, menikmati hasil-hasil alam seperti damar, madu,rotan dan buah-buahan yang ada di hutan. Pada saat hak ekonomi dan social masyarakat local terganggu dan bahkan terancam hilang oleh aktivitas perusahaan maka tanpa disadari akan melahirkan sebuah konflik dalam pengelolaan sumber daya alam (J.O, 2006).

Kondisi ini, menstimulasikan terjadinya resistensi dari masyarakat terhadap kehadiran perusahaan. Kebijakan tata usaha negara yang dikeluarkan oleh pejabat Tata usaha negara (pemerintah indonesia) dalam bentuk perizinan yang diberikan kepada perusahaan untuk mengelola sumber daya alam pada suatu kawasan tanpa ada kajian dan analisis yang baik dan 
benar serta lemahnya akomodasi hukum sehingga berakibat terjadinya konflik hak pengelolaan sumber daya alam antara perusahaan asing dan masyarakat lokal, konflik sumberdaya alam ini bahkan telah menelan banyak korban baik di kalangan perusahaan sendiri maupun masyarakat.

Dalam mengatasi konflik pada sumber daya alam atas hutan, tanah, perkebunan, dan pertambangan menunjukkan peningkatan yang signifikan sering terjadi bahkan konflik-konflik lama yang belum selesai seringkali berujung pada saling menyerang antara masyarakat dengan perusahaan. Pengerahan karyawan dan tenaga bayaran dan kepolisian kerap terjadi atas permintaan dari perusahaan dengan alasan mengamankan aset. Namun fakta dilapangan tujuan pengamanan banyak yang berujung pada pengusiran secara paksa masyarakat dari areal konflik bahkan penembakan, penangkapan, dan pemenjaraan sangat diperlukan efektivitas komunikasi dan pebdkatan budaya.

Bila ada sebuah konflik maka diyakini ada penyebabnya yang dapat dijelaskan dari beberapa faktor-faktor penyebabnya. Faktor penyebab konflik jika dilihat dari penggunaan lahan di Indonesia (Konsorsium Pembaruan Agraria, 2013). Faktor-faktor tersebut diantaranya, Pertama, Pemberian izin lokasi oleh pemerintah dan penetapan kawasan hutan secara sepihak oleh Kementerian Kehutanan. Kedua, Pengelolaan lahan BUMN di wilayah perkebunan warisan kolonial yang terdapat di beberapa propinsi yang menjadikan perkebunan menjadi sektor komoditi utamanya seperti di Sumatera Utara, Sumsel dan lain-lain. Ketiga, Pemberian izin lokasi yang berada di atas tanah-tanah masyarakat seperti transmigrasi (Dahrendorf, 1986).

Tidak adanya kehendak yang kuat dari pemerintah untuk menyerahkan pengelolaan kepada masyarakat. Padahal, secara turun temurun masyarakat adat telah lama memiliki dan menguasai lahan hutan di Indonesia dengan prinsip kelestarian lingkungan (Heru, 2001).

Beberapa hal yang menjadi penyebab konflik yang terjadi antara masyarakat dengan perusahaan perkebunan yang terjadi di antaranya yakni, menuntut ganti rugi lahan, perjanjian pola kemitraan yang dinilai diingkari salah satu pihak, lahan masyarakat masuk ke dalam area konsesi perusahaan, dan penolakan secara umum atas operasi perusahaan di sekitar perkampungan mereka. jumlah pekerja lokal yang tidak seimbang dengan pekerja luar daerah. kearifan lokal dalam pelestarian budaya kurang diperhatikan.

Bahwa konflik yang terjadi antara masyarakat dengan perusahaan perkebunan sebagian besar disebabkan oleh kebijakan pemberian izin pemerintah (pusat maupun daerah) yang tanpa koordinasi terhadap masyarakat setempat dalam perizinan dalam ini kaitan Tata Ruang yang tidak mengakomodir keberadaan ruang-ruang hak masyarakat menjadi sumber masalah utamanya. Seperti sarana dan prasarana jalan dan konservasi hutan, dan lahan masyarakat.

Disisi lain, konflik juga dipicu oleh ketidak jelasan hak antara klaim tradisional masyarakat tempatan/adat (tanah adat/ulayat/turun-temurun) dengan kawasan yang menjadi domain Negara baik berupa kawasan hutan (berupa hutan produksi, lindung, konservasi) maupun non hutan yang diperuntukan bagi pengembangan sektor perkebunan yang rata-rata dipercayakan hak kelolanya kepada swasta. Terkecuali itu, protes dan penolakan masyarakat terhadap operasi perusahaan juga disebabkan oleh adanya pembatasan akses masyarakat akibat ditetapkannya kawasan menjadi kawasan lindung maupun konservasi yang tanpa melalui pertimbangan keberlangsungan keberlanjutan sumber-sumber kehidupanan masyarakat sekitarnya.

Tumpang tindih konflik di masyarakat sering berujung pada tindakan kekerasan, maka kegagalan ini dipicu masyarakat mengajukan tawaran tertinggi kepada pemerintah, yakni penolakan terhadap operasi perusahaan di sekitar lokasi pemukiman meraka. Masalah sengketa atau konflik pertanahan yang terjadi di masyarakat belakangan ini muncul sangat beragam bentuk. Sehingga perlu untuk diidentifikasi guna mencari jalan keluar atau bentuk penyelesaian yang akan dilakukan. 


\section{Pendekatan Mengatasi Masalah Dalam Perkebunan}

Guna mengatasi pendekatan masalah perkebunan dapat dilakukan dilihat dari beberapa pendekatan penting yaitu pendekatan internal dan eksternal. Pendekatan Internal dapat dilakukan dengan, Pertama, Penyuluhan, pendidikan dan penelitian perkebunan, bertujuan mengembangkan kesadaran para petani untuk menggunakan kemungkinan-kemungkinan serta cara-cara baru guna meningkatkan produksinya. Perkembangan teknologi, sedang kemajuan teknologi adalah hasil penelitian. Kegiatan penelitian meliputi berbagai macam percobaanpercobaan.

Kedua, peredaman masalah-masalah sosial dalam masyarakat perkebunan. Masalah sosial perkebunan dapat berbentuk konflik, ahli sosiologi Simmel (Robert, 1997) menganalisa beberapa bentuk atau cara mengakhiri konflik, termasuk menghilangkan dasar konflik dari tindakan-tindakan mereka yang sedang berkonflik, kemenangan pihak yang satu dan kekalahan di pihak yang lain, kompromi, perdamaian dan ketidakmungkinan untuk berdamai. Pertama, Kemenangan satu pihak tidak selalu berarti bahwa pihakyang kalah sama sekali kehilangan semangat dan tenaga untuk Pihak yang kalah mungkin dengan bebas memilih untuk menyerah setelah mereka merasa bahwa hasilnya tidak bisa lainlagi. Dengan demikian pihak yang kalah itu terhindar dari satu keharusan untuk membuang tenaga, suatu usaha yang sia-sia dan sementara itu juga penting untuk menjaga gengsi untuk mampu mengadakan pilihan bebas.

Kedua, Kompromi kelihatannya tidak mungkin terjadi apabila objek konflik tidak dapat dibagikan (artinya tidak dapat dibagikan diantara pihak-pihak yang berkonflik). Tetapi Simmel menunjukkan bahwa kompromi juga dapat dicapai dengan memberikan suatu hadiah "hiburan" kepada pihak yang menderita kekalahan. Sesungguhnya konflik dapat diatasi oleh salah satu pihak dengan menyerahkan sesuatu yang bernilai sebagai pengganti. Ketiga, Hubungan yang sudah didamaikan sangat berbedadengan suatu hubungan yang belum pernah retak. Intensitas hubungan yang sangat tinggi yang kadang-kadang diikuti dengan perdamaian akan terjadi karena adanya ketakutan bahwa keretakanberikutnya tidak dapat didamaikan lagi tanpa meremehkan arti perdamaian yang sebenarnya. Keempat, Beberapa hal perdamaian itu bisa tidak mungkin.Tidak adanya kemungkinan untuk mendamaikan mereka yangberkonflik kadang-kadang mengakibatkan berakhirnya hubungan (Heru, 2001)

. Simmel menunjukkan bahwa alternatif lainnya ada hubungan untuk ditegakkan kembali dimana masalah yang tidak dapat didamaikan itu tidak dibiarkan merusak segi-segi hubungan yang lain. Dengan kata lain pihak yang berkonflik sepakat untuk tidak sepakat. Dalam konteks konflik SDA (Sumber Daya Alam), upaya penyelesaian konflik yang dilakukan oleh masyarakat sangat beragam, mulai dari yang sederhana hingga ke tingkat pengadilan dengan menempuh jalur hukum, seperti melaporkan permasalahan (konflik) kepada pemerintah daerah, Provinsi bahkan sampai kepada lembaga-lembaga penyelenggara Negara, namun itu hanya isapan jempol belaka. Tak heran jika masyarakat melakukan aksi-aksi demonstrasi dengan damai hingga dengan cara-cara yang brutal. Hal ini menunjukkan bahwa tidak adanya keadilan bagi masyarakat serta tidak berpihaknya pemerintah terhadap kepentingan masyarakat.

Artinya masyarakat yang menjadi korban dalam pembangunan, baik di sektor kehutanan, maupun di sektor perkebunan. Pilihan masyarakat juga melakukan penyelesaian konflik dengan perusahaan melalui perundingan. Proses perundingan secara spontan antara dua pihak yang terlibat dalam konflik dianggap sebagai suatu proses penyelesaian yang sederhana dan mempunyai potensi keberhasilan yang cukup tinggi, karena adanya kemauan kedua belah pihak untuk berunding. Namun proses spontan kadang tidak mendapat hasil yang maksimal, maka penyelesaian konflik harus difasilitasi oleh pihak ketiga. Tidak jarang pula proses penyelesaian konflik harus melalui jalur hukum sebagai alternatif terakhir apabila semua cara lain sudah buntu. Namun demikian, di Indonesia jalur hukum sepertinya belum sepenuhnya dapat dipercayai oleh semua pihak yang terlibat, sehingga cara penyelesaian konflik seperti ini jarang digunakan (Susetiawan, 2000). 
Menurut Max Weber dalam sebuah konflik di dalam masyarakat, obat yang memperkuat mereka dari konflik itu merupakan konsepsi baru dari agama, yang mengajarkan mereka untuk memandang pencarian kekayaan tidak hanya sebagai suatu kemajuan, tetapi sebagai sebuah tugas.

Beberapa langkah-langkah yang bisa digunakan dalam penyelesaian konflik yang terjadi menyangkut masyarakat dan perusahaan perkebunan antara lain, Pertama, pemerintah memperbaruhi kebijakan penyelesaian konflik dengan cara membuat kelembagaan independen di level nasional dan daerah yang disertai dengan mekanisme dan prosedur operasional penyelesaian konflik. Kedua, pemerintah memberi ruang bagi lembaga-lembaga mediatorsukarela untuk terlibat dalam penyelesaian konflik baik di level Nasional maupun Daerah. Ketiga, pemerintah harus segera melakukan identfifikasi dan pemetaan terhadap keberadaan hutan dan tanah ulayat sehingga dapat dipedomi para pihak dalam penyelesaian konflik yang didasari atasklaim hak ulayat.

Badan Pertanahan Nasional dan Kementerian Kehutanan seyogianya memiliki kesepahaman dalam menterjemahkan kewenangan penerbitan alas hak dalam kawasan hutan kepada pihak ketiga, sehingga jika terjadi penyelesaian konflik melalui mediasi maka kesepakatan tidak lagi dapat dimentahkan karena alasan, Satu, Penting ditetapkan bahwa terhadap konflik masyarakat dengan perusahaan yang sudah beroperasi, maka harus diberlakukan jeda operasi sementara perusahaan selama proses penyelesaian konflik. Dua, konflik Sumber daya alam harus dipandang sebagai sesuatu yang luar biasa (extraordinary), karena bisa menimbulkan dampak padadimensi yang lebih luas seperti konflik SARA, batalnya investasimasuk, bahkan menyebabkan jatuhnya korban nyawa yang mengarah pada pelanggaran Hak Asasi Manusia (HAM). Tiga, menggiat penyadaran rakyat atas hak-hak tanah sebagai kekuatan dialektis terhadap kekuasaan negara. Gerakan ini dapat dilakukanmelalui tindakan penyadaran dengan pendampingan para aktivissosial (LSM) yang selama ini juga sudah banyak membantu,termasuk tindakan penyadaran dan advokasi (Robert, 1994).

Pihak perusahaan perkebunan diharapkan dapat mematuhi prinsip RSPO (Rountable Sustainable Palm Oil) dimana perusahana harus peduli terhadap masyarakat adat dan tidak berkonflik dengan perusahaan yang berkonflik dengan masyarakat tidak lagi menggunakan aparat kepolisian sebagai tameng untuk menghadapi aksi tuntutan masyarakat, tetapi dapat menyelesaikan dengan bijaksegala yang menjadi perhatian masyarakat maupun pemerintah.

Hal yang tidak kalah penting untuk diperhatikan yaitu bahwa pertentangan yang berwujud konflik tidak hanya terjadi pada kehidupan sosial, melainkan dimana saja berada maka disana pasti ada pertentangan. Sisi lain dari sebuah pertentangan dan konflik itu adalah pada dasarnya sebuah konflik dapat menjadi sarana untuk mencapai keseimbangan kekuatan kekuatan dalam masyarakat. Karena konflik yang timbul merupakan pertanda bahwa akomodasi yang sebelumnya tercapai, tidak dihiraukan lagi. Maka, diadakan perubahanperubahan dalam hungan antara kekuatan-kekuata tersebut sehingga tercapai keseimbangan lagi. Lagi pula, sebuah konflik dapat juga menghasilkan sebuah bentuk kerja sama dengan terjadinya pertentanga tersebut, masing-masing pihak akan melakukan introspeksi, kemudian mengadakan perbaikan-perbaikan (Soerjono Soekanto, 2007). Konflik juga dapat diartikan sebagai kontrol masyarakat terhadap sesuatu tindakan yang salah yang dilakukan oleh pihak perusahaan.

\section{PENUTUP}

Perkebunan secara umum dapat dilihat menjadi dua aspek yaitu aspek internal dan aspek eksternal, dalam peningkatan produksi dan sumber daya manusia di dalam kebun membutuhkan prasana serta tenaga ahli dalam bidang manjement, maka untuk itu diperlukan Penyuluhan, pendidikan dan penelitian. Aspek eksternal dalam perkebunan yaitu masalah sosial yang terdapat di perkebunan adalah masalah konflik masyarakat dan Perusahaan Perkebunan 
Konflik sumberdaya alam adalah manifes maupun laten di sekitar dan berbasiskan perebutan sumberdaya alam. Pelaku konflik sendiri bias perusahaan, masyarakat maupun pemerintah dengan sebab, intensitas keterlibatan dan pola yang berbeda antar para pelaku konflik tersebut.

Efektivitas komunikasi di dalam masyarakat perkebunan tidaklah cukup hanya memiliki kemampuan dalam mengalisa, teknologi serta menejerial tetapi dalam pendekatan permasalahan harus mamapu penguasaan negoisasi, baik kemampuan dialog, kerendahan hati, kepercayaan, harapan dan pemikiran kritis, agar permasalah dalam kebun tidak meluas dan akan tidak menguntungan semua pihak.

\section{DAFTAR PUSTAKA}

Dahrendorf, R. (1986). Konflik dan konflik dalam masyarakat industri: Sebuab Analisa Kritik. Jakarta: Rajawali.

Dharma, K.D. (2016). Struktur Fudamental Pedagogik (1 ed., Vol. 1). (M. D. Wildani, Penyunt.) Bandung: PT Refika Aditama.

Dirman, C.J. (2014). Komunikasi Dengan Peserta Didik. Jakarta: PT Redika Cipta.

Hasbiansyah. (1996). Effective Communication. Unisba Bandung: Moss, Stewart L.tubbs dan Sylvia.

Heru, N. (2001). Negara, pasar dan Keadilan Sosial. Yogyakarta: Pustaka Pelajar Offset.

J, O. (2006). Perkembangan Pertanian di Indonesia. Yogyakarta: Gajah mada University Press. Onong, U. (1999). Komunikasi teori dan praktek. Bandung: PT. Remaja Rosdakarya.

Robbins, S. (2001). Perilaku Organisasi. Jakarta: PT. Prenhallindo.

Robert, L. (1994). Teori Sosioligi Klasik dan Modern. Jakarta: Gramedia Pustaka Utama.

Siagian, S. P. (1997). Filsafat Adminstrasi. Jakarta: Rineka Cipta.

Soekanto, S. (2007). Sosiologi suatu Pengantar. Jakarta: PT Raja Grafindo Persada.

Susetiawan. (2000). konflik Sosial Kajian Sosiologi hubungan buruh, Perusahaan dan Negara di Indonesia. Yogyakarta: Pustaka Pelajar offset. 